\title{
Molecular and cellular underpinnings of normal and abnormal human placental blood flows
}

\author{
Yingchun Li', Ramón A Lorca' and Emily J Su² \\ 1Department of Obstetrics and Gynecology, Division of Reproductive Sciences, University of Colorado School of Medicine, Aurora, Colorado, USA \\ ${ }^{2}$ Department of Obstetrics and Gynecology, Division of Maternal-Fetal Medicine/Division of Reproductive Sciences, University of Colorado School of \\ Medicine, Aurora, Colorado, USA \\ Correspondence should be addressed to E J Su: emily.su@ucdenver.edu
}

\begin{abstract}
Abnormal placental function is well-established as a major cause for poor pregnancy outcome. Placental blood flow within the maternal uteroplacental compartment, the fetoplacental circulation or both is a vital factor in mediating placental function. Impairment in flow in either or both vasculatures is a significant risk factor for adverse pregnancy outcome, potentially impacting maternal well-being, affecting immediate neonatal health and even influencing the long-term health of the infant. Much remains unknown regarding the mechanistic underpinnings of proper placental blood flow. This review highlights the currently recognized molecular and cellular mechanisms in the development of normal uteroplacental and fetoplacental blood flows. Utilizing the entities of preeclampsia and fetal growth restriction as clinical phenotypes that are often evident downstream of abnormal placental blood flow, mechanisms underlying impaired uteroplacental and fetoplacental blood flows are also discussed. Deficiencies in knowledge, which limit the efficacy of clinical care, are also highlighted, underscoring the need for continued research on normal and abnormal placental blood flows.
\end{abstract}

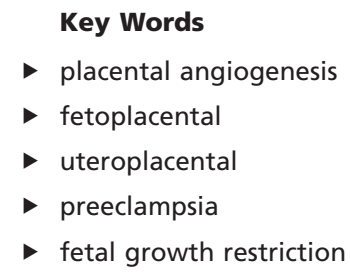

Journal of Molecular

Endocrinology

(2018) 60, R9-R22

\section{Introduction}

Placental blood flow is a critical component of pregnancy outcome. Human placental blood flow comprises two separate compartments - the maternally derived uteroplacental circulation and the fetoplacental vasculature. This hemochorial villous placenta allows for maternal blood to directly bathe syncytiotrophoblast (STB), which becomes progressively apposed to the fetoplacental endothelium as gestation progresses, allowing for nutrient/waste and gas exchange to occur. While trophoblast, stromal and endothelial functions and interactions are also vital factors influencing pregnancy outcome, abnormal uteroplacental and fetoplacental blood flows, both individually and in combination, are strongly associated with adverse perinatal outcome, posing risks to maternal well-being and to immediate and long-term health of the infant.

\section{Clinical implications of abnormal placental blood flow}

Abnormal placental blood flow, either on the maternal side, fetal side or both, has been implicated in various complications of pregnancy such as preeclampsia (PE) and fetal growth restriction (FGR). For instance, one key component to the pathogenesis of PE and perhaps placentally mediated FGR, as well, is thought to be defective trophoblast invasion into the maternal spiral arteries (Zhou et al. 1993, 1997a, Kaufmann et al. 2003). 
This results in abnormally narrow and tortuous uterine vessels that result in placental hypoperfusion and uteroplacental ischemia.

Within the fetal compartment, placental vascular resistance should normally be low, allowing for forward flow through the umbilical arteries during both fetal cardiac systole and diastole (Giles et al. 1985, Trudinger et al. 1985c). In high-risk pregnancies that can be seen in PE and/or FGR, placental findings that lead to abnormally elevated placental vascular resistance include vasoconstricted stem villous vessels and impaired fetoplacental vascular angiogenesis can be seen in PE and/or FGR (Salafia et al. 1995, 1997, Kingdom et al. 1997, Su et al. 2015). This is seen clinically through abnormal umbilical artery Doppler velocimetric indices, where diastolic forward flow is initially impaired and can eventually become absent or reversed (Giles et al. 1985). When severe enough, the fetus is at a high risk for prolonged exposure to in utero hypoxemia/acidemia or stillbirth (Baschat \& Weiner 2000, Alfirevic et al. 2017).

Clinically, the 'treatment' for both entities is delivery. With PE, it is removal of the placenta after delivery that cures the maternal manifestations of the disease. With isolated FGR, delivery is the only method to prevent prolonged exposure to an abnormal in utero environment and stillbirth (Group 2003, Lees et al. 2015). The problem, though, is that in severe cases, delivery oftentimes needs to occur at very preterm gestational ages with the attendant consequences of prematurity such as blindness, deafness, mental retardation, cerebral palsy and chronic medical problems (Group 2003, Thornton et al. 2004). Furthermore, even if these infants are fortunate enough to evade the potentially severe complications of the perinatal period, they are at an increased risk for developing obesity, cardiovascular disease and metabolic syndrome later in life (Barker \& Thornburg 2013). Thus, a better understanding of the mechanisms underlying normal and abnormal placental blood flows in both maternal and fetoplacental compartments is vital if clinical outcomes are truly to be improved.

\section{Development of uteroplacental blood flow}

Uteroplacental blood flow develops soon after implantation. By post-fertilization day 6, the blastocyst has attached to the endometrial surface, with partial embedding and contact with the endometrial stroma by day 8 (Schlafke \& Enders 1975, Sadler 1995). Lacunae, spaces within the early syncytiotrophoblastic layer of the chorion, begin to appear within the syncytium, and these fuse to maternal sinusoids by day 12 after fertilization (Enders 1989). Once maternal blood flows through this compartment, the rudimentary uteroplacental circulation is established. The fusion of lacunae to maternal sinusoids eventually forms the intervillous space of the placenta, and ultimately, the spiral arteries of the uterus directly communicate with this intervillous space, resulting in uteroplacental blood flow that is clinically evident during pregnancy.

Approximately two to three weeks after fertilization, interstitial trophoblasts, one type of extravillous trophoblasts (EVTs), further migrate through the endometrial stroma, penetrate the decidua and adjacent myometrium and gather around spiral arteries. This is thought to prepare the spiral artery for endovascular trophoblast invasion (Pijnenborg et al. 1980). Endovascular trophoblasts, another type of EVTs, then invade and migrate down the lumens of the spiral arteries (Fig. 1) (Zhou et al. 1997a, Red-Horse et al. 2005, Fisher 2015). They initially form cell plugs within the terminal portions of the spiral arteries, which results in destruction of maternal vascular endothelium via apoptotic mechanisms (Kaufmann et al. 2003, Harris et al. 2006). Vascular smooth muscle cells and elastic fibers of the vascular media are replaced with fibrinoid, aiding transformation into a low-resistance circuit (Brosens et al. 1967, Harris 2010). Simultaneously, these plugs are dissolved and the functional maternal circulatory component of the placenta is established.

From a molecular perspective, multiple coordinated events that have yet to be completely elucidated occur. For successful invasion to occur, trophoblastic phenotype must change from an epithelial to endothelial composition. For instance, during normal pregnancy, downregulation of epithelial-like adhesion molecules such as $\alpha 6 \beta 4$ integrin and concomitant upregulation of adhesion molecules more typical of endothelial cells, including $\alpha 5 \beta 1$ and $\alpha 1 \beta 1$, occur in cytotrophoblasts (Damsky et al. 1992, 1994, Zhou et al. 1997b). Invasive EVTs also produce various proteases, such as matrix metalloproteinases to degrade the extracellular matrix, but excessive trophoblast invasion is also being limited by EVT production of protease inhibitors, including tissue inhibitors of metalloproteinases and plasminogen activator inhibitors (Librach et al. 1991, Damsky et al. 1992, Shimonovitz et al. 1994). Together, these underlying mechanisms allow endovascular EVTs to migrate through the endothelium, where maternal uterine artery endothelial and vascular smooth muscle cells then undergo apoptosis and are replaced by these trophoblasts, which have assumed an endothelial-like phenotype 


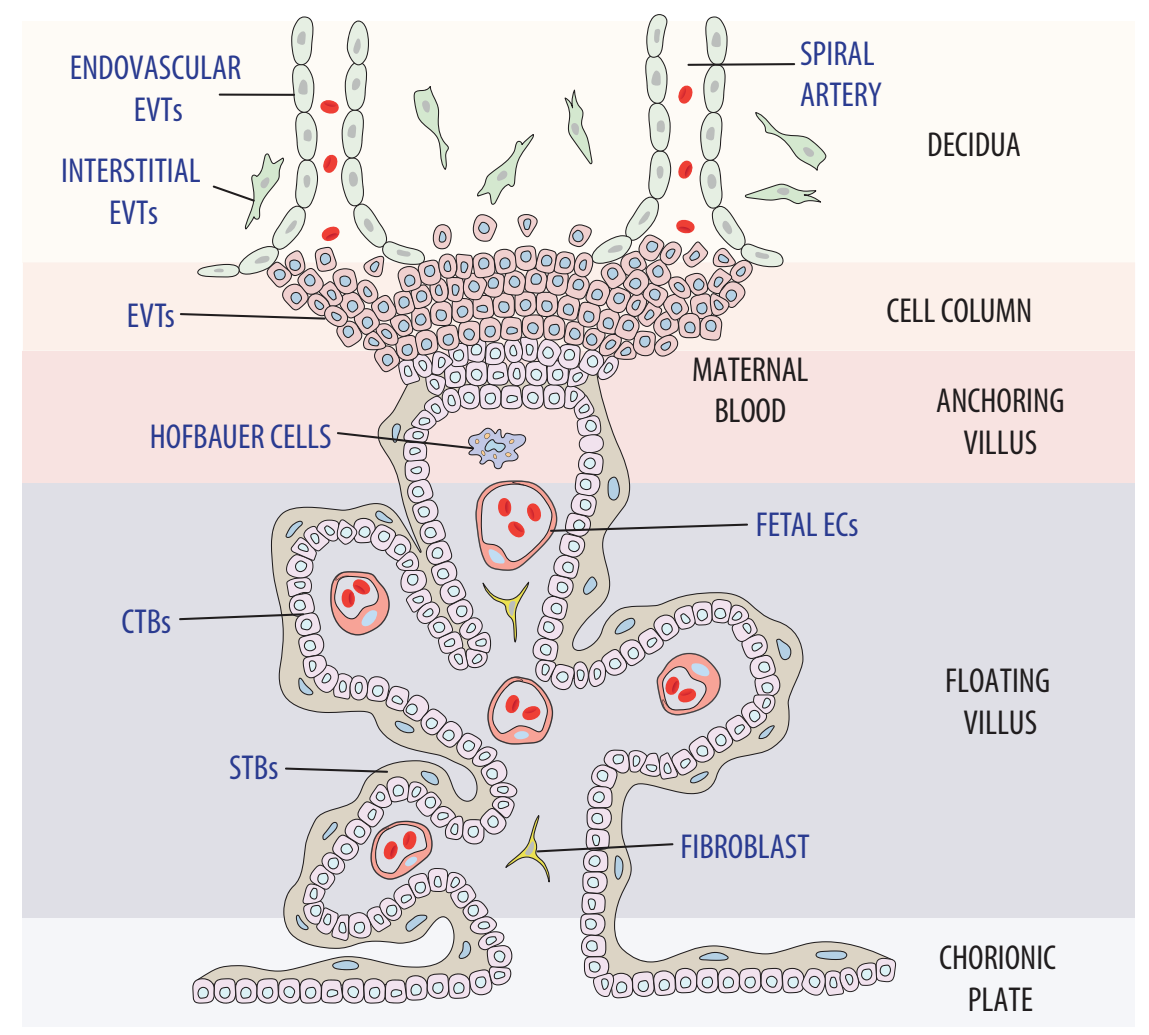

\section{Figure 1}

Formation of the uteroplacental circulation. EVTs migrate from the cytotrophoblastic shell into the endometrium. Interestitial EVTs prepare the spiral artery for endovascular EVTs. Endovascular EVTs then invade and migrate down the lumens of spiral arteries as they approach the decidua. The cell plugs that are initially formed destroy maternal vascular endothelium via apoptosis and replace vascular smooth muscle cells and elastic fibers from the media with fibrinoid. After dissolution of these plugs, the maternal circulatory component of the placenta is established.
(Pijnenborg et al. 1983, Kam et al. 1999, Harris et al. 2006). Ultimately, these normal processes allow for development of a low-resistance maternal vascular compartment with maternal blood flowing from maternal spiral arteries to the intervillous space by about 10-12 weeks of pregnancy (Hustin \& Schaaps 1987, Rodesch et al. 1992, Jaffe et al. 1997).

\section{Expansion of the fetoplacental circulation}

With regard to the fetoplacental circulation, development of the placental villi starts around day 13 after conception. Mesodermal cells within the villus core initiate the process of vasculogenesis by differentiating into small blood vessels starting approximately 21 days postfertilization (Castellucci \& Kaufmann 1982, Demir et al. 1989, Sadler 1995). These capillaries within the villus fuse with capillaries developing within the mesoderm of the chorionic plate and connecting stalk, and ultimately they establish contact with the intraembryonic circulation, forming the fetoplacental circulation (Castellucci et al. 1990, Sadler 1995).

The fetoplacental circulation then continues to expand via a gradual transition from vasculogenesis to angiogenesis between 32 days post-conception to approximately 9 weeks after fertilization (Kaufmann et al. 1985,
Castellucci et al. 1990, van Oppenraaij et al. 2009). Thereafter, angiogenesis continues throughout gestation but exponentially accelerates beginning at approximately 25 weeks' gestation (23 weeks post-fertilization), resulting in a vascular bed that is approximately $550 \mathrm{~km}$ in length and $15 \mathrm{~m}^{2}$ in surface area (Fig. 2) (Burton \& Jauniaux 1995, Mayhew 2002). Physiologically, this corresponds to decreasing fetoplacental vascular resistance as demonstrated by increasing end-diastolic velocities within the umbilical artery as gestation progresses (Thompson \& Trudinger 1990, Guiot et al. 1992, Todros et al. 1992). Much remains unknown regarding the mechanistic underpinnings of normal human fetoplacental vascular development, but various growth factors have been shown to be key players in both vasculogenesis and angiogenesis.

\section{Vascular endothelial growth factor (VEGF) family}

One key group of factors is the VEGF family, and most notably for placental angiogenesis, VEGFA. The critical importance of VEGF and its two main receptors (1) VEGF receptor 1, also known as FMS-like tyrosine kinase 1 (FLT1) and (2) VEGF receptor 2 or kinase insert domain (KDR) - is demonstrated by the finding of embryonic lethality due to abnormal blood vessel formation during embryogenesis in: (1) Vegf knock-out mice, (2) Flt1 


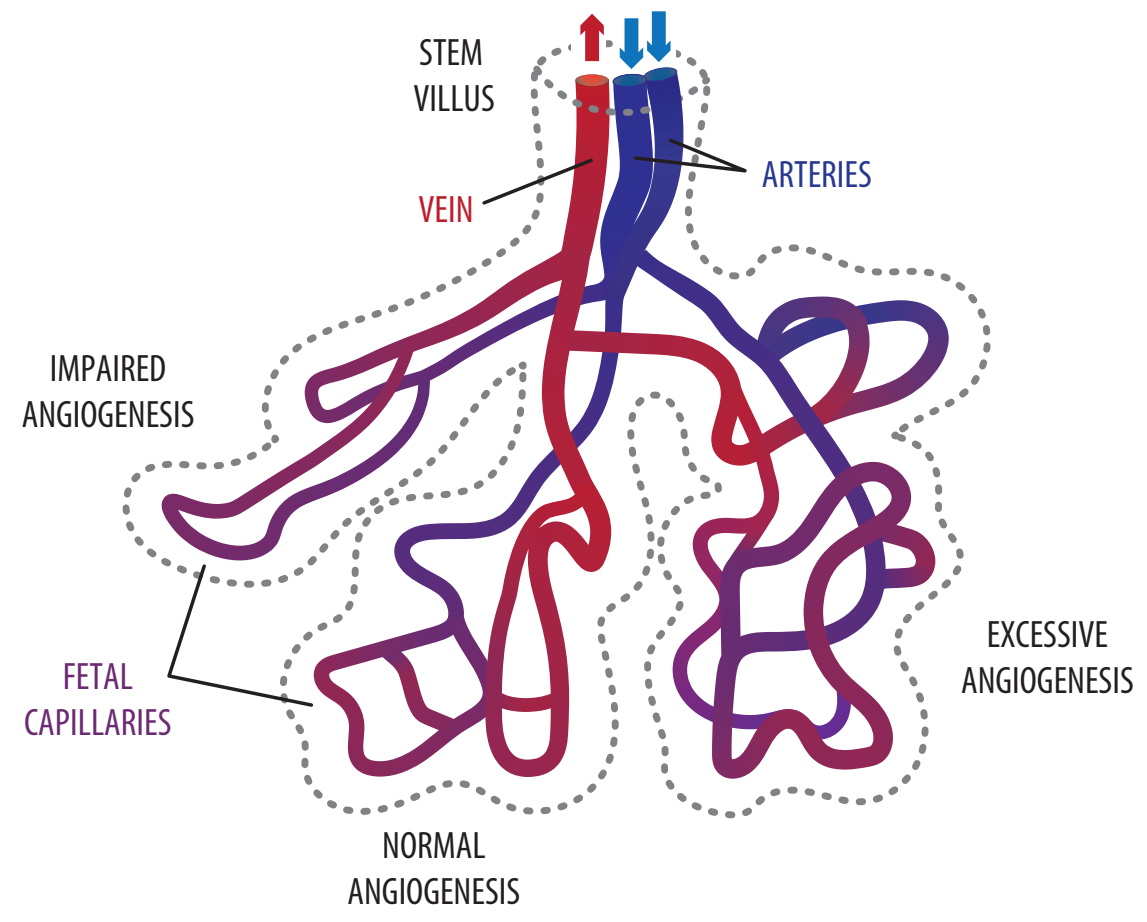

\section{Figure 2}

Fetoplacental angiogenesis. Throughout the second half of pregnancy, fetoplacental angiogenesis continues, resulting in villous capillary beds that are appropriately branched (normal angiogenesis). This allows for a structurally mediated decrease in fetoplacental vascular resistance. In pregnancies subjected to hypoxia such as high altitude or severe maternal anemia, excessive angiogenesis occurs, although placental vascular resistance is not adversely affected in these scenarios. When severe FGR and/ or PE are present, villous capillary angiogenesis is impaired, resulting in thin, elongated vessels that anatomically contribute to abnormally elevated fetoplacental vascular resistance. knock-out mice and (3) $K d r$ knock-out mice (Fong et al. 1995, Shalaby et al. 1995, Carmeliet et al. 1996). Even mice lacking a single Vegf allele demonstrate abnormal blood vessel development and embryonic lethality (Carmeliet et al. 1996). Within humans, VEGFA is highly expressed in cytotrophoblast cells early in pregnancy, whereas FLK1 and KDR are primarily expressed within the hemangiogenic cords, with a predominance of KDR (Demir et al. 2004). This suggests that paracrine signaling may help to drive fetoplacental vasculogenesis. As gestation progresses, the VEGFA expression decreases within trophoblast while increasing within fetoplacental endothelial, mesenchymal and Hofbauer cells (Demir et al. 2004).

Based upon animal studies, Vegfa binding to Flt1 and/or Kdr within endothelial cells triggers various signal transduction cascades that result in endothelial proliferation and migration. For instance, in ovine fetoplacental artery endothelial cells, VEGFA induces activation of several signal transduction cascades including the PI3-kinase (PI3K)/AKT1 pathway (Zheng et al. 2008, Liao et al. 2010). PI3K inhibition results in suppressed nitric oxide (NO) production and completely blocks VEGFA-mediated cell proliferation and migration (Zheng et al. 2008). In Akt1 knock-out mice, there is also a marked reduction in endothelial nitric oxide synthase (NOS3) phosphorylation (Lee et al. 2014). In vivo findings also demonstrate significance of the PI3K/AKT1 pathway. For example, in endothelial-specific, postnatal deletion of
$A k t 1$, retinal angiogenesis is impaired with delayed radial outgrowth and reduced endothelial coverage (Lee et al. 2014). Furthermore, the placentas of Akt1-null mice show decreased placental vascularization, which is thought to contribute to both growth restriction and neonatal mortality in the pups (Chen et al. 2001, Yang et al. 2003).

Placental growth factor (PGF) is also a member of the VEGF family and is expressed in trophoblast. Unlike VEGFA isoforms, however, it is only able to bind to FLT1 and not KDR. Initially considered a simple competitive inhibitor of VEGFA effects through FLT1, it is also capable of stimulating the growth of endothelial cells in vitro, promoting proliferation, survival and migration (Maglione et al. 1991). This was thought to occur by increasing VEGFA availability to bind to KDR (Park et al. 1994). More contemporary data, especially within the cancer literature, suggest that PGF also has direct angiogenic effects, with PGF homodimers and PGF/VEGFA heterodimers being pro-angiogenic both in vitro and in vivo (Autiero et al. 2003a,b, Fischer et al. 2007, Yang et al. 2013). However, other studies suggest that PGF, especially when elevated, can decrease angiogenic activity within tumors (Eriksson et al. 2002, Xu et al. 2006).

\section{Fibroblast growth factors (FGFs)}

The family of FGFs are known to regulate several cellular processes, including proliferation, differentiation, 
migration and survival (Beenken \& Mohammadi 2009). Specific to the human placenta, FGF2 is currently considered the main FGF. Its expression has been localized to the cytotrophoblast in the first trimester and primarily to the fetoplacental endothelium at term, with low expression in STBs (Ferriani et al. 1994, Shams \& Ahmed 1994, Arany \& Hill 1998). FGF10 has also been described in the placenta, but its role appears to primarily mediate chorionic villous growth (Natanson-Yaron et al. 2007). FGF activity is mediated by a family of FGF receptors (FGFR1-4) that are members of the receptor tyrosine kinase family. While the human placenta has been shown to express all the FGFRs, FGFR1 appears to be the only FGFR expressed within the fetoplacental vasculature to date (Arany \& Hill 1998, Anteby et al. 2005).

The majority of knowledge surrounding the role of FGFs and placental angiogenesis is derived from animal studies. Ovine fetoplacental arterial endothelial cells, which also express FGF2 in vivo and in vitro, have been demonstrated to undergo activation of ERK1/2 and PI3K/AKT1 pathways via phosphorylation of FGFR1 (Feng et al. 2012). In contrast to VEGFA stimulation of these endothelial cells, inhibition of either signaling pathway only partially inhibits FGF2-stimulated proliferation (Zheng et al. 2008). Interestingly, FGFR1 is confined within plasma membrane caveolae, with the regulatory protein caveolin-1 interacting with FGFR1 (Feng et al. 2012). This allows FGF2/FGFR1-mediated activation of both MAPK and PI3K/AKT1 cascades, which, in turn, enhances various measures of angiogenesis including endothelial cell migration and tube formation (Feng et al. 2012).

\section{Angiopoietins}

Angiopoietins are a group of four angiogenic growth factors (ANGPT1, ANGPT2, ANGPT3 and ANGPT4) that regulate angiogenesis via binding to the TEK receptor tyrosine kinase (TEK, also known as TIE2). ANGPT1, ANGPT2 and TEK are expressed within the human placenta (Dunk et al. 2000, Goldman-Wohl et al. 2000, Zhang et al. 2001, Geva et al. 2002, Seval et al. 2008, De et al. 2016). There is some discrepancy between studies regarding the exact localization of expression of ANGPT1, ANGPT2 and TEK during the course of gestation. However, there is consensus that TEK is expressed within endothelium of placental blood vessels, and the majority of studies suggest that the ANGPT1:ANGPT2 ratio increases as gestation progresses (Dunk et al. 2000, Zhang et al. 2001). More recently, data suggest that there are intraplacental variations, with the ANGPT1 and TEK expression being higher in the periphery of the placenta and higher expression of ANGPT2 within the central regions of the placenta (De et al. 2016). Taken in the context where ANGPT2 activation of TEK results in destabilization of the vessels, allowing them to remain plastic and capable of responding to other angiogenic factors such as VEGFA, this suggests that in early pregnancy and within the more central portion of the villous vascular tree, high levels of ANGPT2 allow for progression of angiogenesis. In contrast, as gestation progresses or as vessels grow outward to the periphery of the placenta, increases in ANGPT1mediated phosphorylation of TEK allows for these newly formed vessels to be stabilized via EC survival and EC-EC interactions (Dunk et al. 2000, Zhang et al. 2001, Geva et al. 2002).

\section{Mechanisms underlying abnormal placental blood flow}

Clinically, abnormal placental blood flow can be detected in the maternal uteroplacental compartment, the fetoplacental vasculature or both. Aberrant uterine artery and/or umbilical artery Doppler velocimetry are suggestive of placental insufficiency and are individually associated with an increased risk for adverse pregnancy outcome (Alfirevic et al. 2013, Garcia et al. 2016). Based upon Doppler studies, impairment of flow in either vascular compartment can occur in isolation or concurrently (Brosens et al. 1977, Trudinger et al. 1985a,b,c). Ovine studies, however, suggest more interdependence between maternal and fetoplacental circulations. With decreases in uterine perfusion, there is a corresponding reduction in fetoplacental blood flow (Stock et al. 1980). Similarly, the umbilical circulation has also been shown to locally regulate uterine blood flow (Rankin et al. 1975). Nevertheless, based upon clinical studies and for the purpose of clarity in this review, the two vascular compartments are discussed separately.

\section{The maternal uteroplacental vasculature}

Abnormalities of maternal uteroplacental blood flow often manifest clinically as PE with and without FGR. It is now well-established that defects in both EVT invasion and spiral artery remodeling that are characteristic of hypertensive disorders in pregnancy and FGR lead to abnormal placentation (Kaufmann et al. 2003, Pijnenborg et al. 2006). In turn, the placenta becomes ischemic, which is then thought to result in the release of soluble factors 
that cause maternal systemic endothelial dysfunction, ultimately leading to the phenotype of PE (Kaufmann et al. 2003, Pijnenborg et al. 2006).

\section{Deficient EVT invasion and impaired spiral artery remodeling}

Although likely not the only culprit, much of the impairment in maternal uteroplacental blood flow is initially triggered by compromised EVT invasion of the uterine stroma and vasculature. This is evidenced by histologic sections of placental bed biopsies in patients with PE, where cytotrophoblasts were located farther from uterine vessels than in sections of control placentas (Zhou et al. 1997a). Furthermore, when spiral arteriole endovascular cytotrophoblasts were detected, invasion within the vessel did not exceed the depth of the superficial decidua (Zhou et al. 1997a). These findings have been shown to be mediated, at least in part, by the failure of transformation from epithelial- to endotheliallike phenotype with an abnormally persistent expression of epithelial adhesion molecules such as E-cadherin and

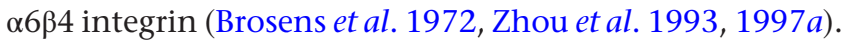

Although impaired trophoblast invasion is an important source for abnormal spiral artery remodeling, a defective decidualization process has also been proposed to affect uteroplacental blood flow. Some evidence indicates that changes in the endometrium before EVT invasion are distinct in preeclamptic women. For instance, deciduadependent secretion of insulin-like growth factor bind protein-1 is reduced during the first trimester of women who later develop PE as compared to normal pregnancies (Hietala et al. 2000, Vatten et al. 2008). This suggests a maternal component for altered uteroplacental perfusion. Other studies have shown that maternal macrophages are concentrated around suboptimally remodeled spiral arteries from preeclamptic women and that those macrophages secrete tumor necrosis factor-alpha and indoleamine 2,3-dioxygenase to induce apoptosis in EVTs (Reister et al. 1999, 2001).

Invasive trophoblasts are further regulated by their interaction with other cells including decidual natural killer (NK) cells. NK cells secrete various chemokines, and for NK cells and trophoblast to interface, the trophoblast must express matching chemokine receptors (Hanna et al. 2006). Additionally, NK cell function is also mediated by $\mathrm{NK}$ receptors that bind to MHC class I molecules among other ligands. EVTs express HLA-C as their sole polymorphic classical MHC class 1 molecule, and given paternal contributions, HLA-C alleles can be different to that from the mother. Furthermore, NK cells express an incredibly diverse range of killer immunoglobulin receptors (KIRs) resulting from differences in gene number between individuals and allelic diversity at individual KIR loci (Parham \& Moffett 2013). Specific maternal KIR haplotypes have been found to increase the risk of PE, demonstrating that immune recognition also plays a role in the regulation of uteroplacental blood flow (Hiby et al. 2010).

\section{Uteroplacental hypoperfusion resulting in maternal systemic EC dysfunction}

Several lines of evidence support that abnormal uteroplacental blood flow with subsequent poor placental perfusion strongly contributes to the phenotype of PE. For example, the incidence of PE is higher in women who live at high altitudes, where there is some degree of relative hypoxia (Palmer et al. 1999, Zamudio 2007). Additionally, medical comorbidities resulting in vascular insufficiency, such as preexisting hypertension, acquired thrombophilias and renal disease increase the risk for impaired placentation, PE and FGR (Dekker 1999, Bartsch et al. 2016). Perhaps most compellingly, animal models whose uteroplacental blood flow has been reduced demonstrate phenotypes strongly suggestive of PE (Khalil \& Granger 2002, Bird et al. 2003, Ianosi-Irimie et al. 2005, Karumanchi \& Stillman 2006).

Much of the maternal clinical phenotype of PE is thought to arise from maternal endothelial dysfunction. During normal pregnancy, uterine artery vasodilation has been found to be mediated, at least in part, by enhanced NO production. This occurs not only via NOS3 phosphorylation, but also through other mechanisms including enhanced gap junction communication which contributes to amplified and sustained intracellular calcium bursts (Tran et al. 2009, Yi et al. 2010, 2011). In PE, uterine artery ECs are unable to produce the normally augmented levels of NO that occur during normal pregnancy, and this is thought to be one major mechanism resulting in insufficient vasodilation (Sladek et al. 1997, Bird et al. 2003, Savvidou et al. 2003).

\section{The fetoplacental vasculature}

As noted earlier, fetoplacental vascular resistance should normally decrease as gestation progresses, allowing for increased forward flow through the umbilical arteries during fetal systole. For this to occur, there are at least two main requirements: (1) Proper placental vasomotor 
tone and (2) appropriate expansion of the fetoplacental vasculature via angiogenesis. When either or both these core principles are disrupted, fetoplacental vascular resistance may become abnormally elevated.

\section{Constricted vasomotor tone}

In contrast to small arterioles of other vascular beds, vasomotor tone of placental chorionic plate and stem villous vessels, which are similar in size to these arterioles, are not under autonomic control as placental vessels lack innervation (Fox \& Khong 1990, Poston et al. 1995, Sabry et al. 1995, Reilly \& Russell 1977). Not only are these larger placental vessels controlled primarily by humoral influences, they also respond differently than other vessels outside of the placenta. For instance, the response of the placental vasculature to factors such as acetylcholine, angiotensin II and bradykinin is blunted (Mak et al. 1984, McCarthy et al. 1994). Issues such as vessel diameter have also been shown to affect sensitivity to factors such as thromboxane A2 (TXA2), with a selective decrease to TXA2 with decreasing vascular diameter in stem villous arteries (Broegger et al. 2016). Placental vessels also vasoconstrict when subjected to prostaglandin E2 (PGE2), whereas all other vascular beds, including maternal uterine vessels, vasodilate under the influence of PGE2 (Glance et al. 1986, Allen et al. 1989, Boura \& Walters 1991, Sastry et al. 1997).

Much of the current knowledge surrounding regulation of human fetoplacental vasomotor tone is extrapolated from in vitro models and studies of humoral factors in cord blood. For example, results from a dualperfused single cotyledon model showed that vessels within FGR placentas had reduced reactivity to PGE2 stimulation in comparison to control placentas (Luria et al. 2012). In a study where cordocentesis was performed in pregnancies complicated by FGR, all of whom had umbilical artery Dopplers suggestive of abnormally elevated placental vascular resistance, significantly higher fetal concentrations of endothelin-1 were found in contrast to gestational age-matched, appropriately grown controls (Rizzo et al. 1996). The same authors also found that the stable metabolite of the vasodilator prostacyclin, 6-keto prostaglandin F1-alpha, was lower in cord blood of FGR pregnancies.

The specific molecular mechanisms underlying the changes in prostanoid levels or of these unique placental vascular responses remain unidentified. There is a small body of literature suggesting that cyclooxygenase-2 (PTGS2) may play a role, although the data are conflicting as to whether it is upregulation or downregulation of
PTGS2 that is resulting in abnormal vasoconstriction. In general, PTGS2 inhibition has been shown to alter the prostacyclin to thromboxane A2 ratio, leading to a prostanoid phenotype that favors vasoconstriction (Howard et al. 2003). A different study found that polymorphisms of the fetal PTGS2 gene that correlate with decreased PTGS2 expression are associated with abnormal placental blood flow and FGR (Polydorides et al. 2007). Chronic glucocorticoid treatment of chorionic plate arteries results in decreased PTGS2 expression and increases vascular resistance, although glucocorticoid treatment was shown to have effects on several other vasoactive mediators (Nugent et al. 2013). In contrast, we have found an upregulation of PTGS2 expression and activity within the endothelium of stem villous vessels in pregnancies complicated by FGR with abnormally elevated fetoplacental vascular resistance in comparison to gestational age-matched controls (Su et al. 2011). However, our studies also suggest that this may be regulated by estrogen receptor-beta, which concomitantly regulates downstream prostanoid synthases resulting in a vasoconstrictive prostanoid profile (Su et al. 2009, 2011). These differences in mechanistic findings may be explained by disparities in types of samples collected (e.g. normal vs pathologic, cell vs tissue studies) or may represent compensatory, rather than pathologic, mechanisms. As an example, NO also regulates placental blood flow and is produced primarily via NOS3 in the placenta. One group of investigators found that the NOS3 expression was significantly higher in endothelium of stem villous vessels in pregnancies complicated by FGR in comparison to controls, suggesting that NOS3 does not contribute to the pathologic phenotype of abnormal placental blood flow but may be an adaptive response to increased fetoplacental vascular resistance (Myatt et al. 1997).

\section{Deficient formation of the fetoplacental vasculature}

Even when there is no disturbance in vasomotor tone, vascular resistance of the fetoplacental circulation is also mediated by the structure of the placental vasculature itself. When fetoplacental vascular resistance is abnormally elevated, as clinically manifested by decreased, absent or reversed umbilical artery end-diastolic velocities, several groups of investigators have previously shown that there are fewer, more slender, and substantially longer and unbranched villous capillary loops than in placentas of uncomplicated pregnancies (Jackson et al. 1995, Macara et al. 1995, 1996, Krebs et al. 1996, Todros et al. 1999, 
Chen et al. 2002) (Fig. 2). This results in fewer vascular conduits, resulting in a structural cause for abnormally elevated placental vascular resistance. These findings have been attributed to excessive non-branching angiogenesis (Benirschke 2012, Mayhew 2002, Mayhew et al. 2004). In actuality, however, whether the cause is too much nonbranching angiogenesis, impaired branching angiogenesis or a combination of both entities remains unknown.

There are both limited and conflicting data regarding the expression of angiogenic factors in placental pathologies associated with abnormal fetoplacental blood flow. For instance, within a hyperthermic ovine model of placental insufficiency-derived FGR where these fetuses manifest abnormal umbilical artery Doppler indices, the cotyledonary VEGFA mRNA expression was actually increased in placentas of FGR fetuses at the equivalent gestational age of the late first trimester (50 days postconception) (Regnault et al. 2002, Barry et al. 2008). This difference, however, disappeared by what could be considered the late second trimester (90 days postconception) (Regnault et al. 2002). This suggests that there may be gestational age-dependent roles of certain angiogenic mediators. In a study of human placentas, one group found that total placental RNA expression of VEGFA was actually increased in the FGR group as compared to the control group (Szentpeteri et al. 2013). This study, however, did not discuss several key maternal characteristics, including gestational age at delivery and number of subjects with abnormal umbilical artery Doppler velocimetry. Additionally, use of total placental RNA further limits interpretation of this finding. Cell-specific VEGFA has also been investigated, primarily through immunohistochemistry, with various studies showing no difference in VEGFA protein expression in pregnancies complicated by FGR, unlike the previously mentioned studies that investigated mRNA expression (Helske et al. 2001, Gurel et al. 2003). Umbilical cord blood levels have also been investigated, and in a cohort of FGR from Spain that, on average, required a late preterm delivery, there was also no difference in umbilical arterial or umbilical venous VEGFA and sFLT1 concentrations (Borras et al. 2014). However, in this study, umbilical artery Doppler pulsatility indices did not significantly differ between the two groups and at worst were only mildly elevated in the FGR group, suggesting that these were not the fetuses that suffered from abnormally high fetoplacental vascular resistance. Taken together, these data suggest that the mechanisms underlying the development of abnormal fetoplacental vascular resistance are much more complex than just VEGFA mediation.
With regard to PGF, data also differ. In the hyperthermic ewe model of FGR that also demonstrates abnormal umbilical artery Doppler velocimetry, there was no difference in PLGF at either 50 or 90 days postconception (Regnault et al. 2002). Recently, one study found that the total placental PGF expression was diminished in cases of severe FGR requiring preterm delivery, and the authors concluded that this may indicate a role of PGF in placental angiogenesis (Joo et al. 2017). No other specific data regarding PGF and fetoplacental angiogenesis have been described to our knowledge, but it warrants comment, especially given its potential effects on angiogenesis and its interaction with VEGFA.

Knowledge surrounding FGF, the angiopoietins and placental blood flow is also limited. Based upon cordocentesis data, FGF2, which again is considered the primary placental FGF, appears to peak at approximately 18-20 weeks with a slow decrease all the way until term (Hill et al. 1995). There was also a trend toward lower FGF2 levels in cord serum of pregnancies that resulted in SGA fetuses, but this was not statistically significant (Hill et al. 1995). As for the angiopoeitins, in a model of FGR derived from overnourished, adolescent, pregnant ewes, the vascularity of the placental cotyledon was decreased, with elevated ANGPT2 expression within these cotyledons in comparison to appropriately grown controls (Carr et al. 2016). In humans, data are more discrepant. For instance, studies have found diminished ANGPT2 expression within total placenta of pregnancies complicated by severe FGR or PE as compared to gestational age-matched controls (Dunk et al. 2000, Zhang et al. 2001). In contrast, a more recent study showed that ANGPT2 and TEK expression was lower, while ANGPT1 was higher in preeclamptic or preeclamptic/FGR pregnancies (Kappou et al. 2014). This study, however, utilized cases that were all mild enough to be delivered at term, suggesting that these fetuses and placentas were less likely to have experienced abnormal placental blood flow.

In addition to the gaps in knowledge surrounding levels of angiogenic mediators and deficient placental vascularization, the molecular mechanisms underlying this impairment also remain incompletely understood. Murine studies demonstrate that knock-out of aryl hydrocarbon receptor nuclear translocator (ARNT), a heterodimeric partner to hypoxia inducible factor 1-alpha (HIF1A) that induces transcription of angiogenic genes such as VEGFA, results in embryonic lethality secondary to deficient placental vascularization (Kozak et al. 1997, Maltepe et al. 1997). Within human fetoplacental endothelial cells isolated from severely growth-restricted 
fetuses with absent or reversed umbilical artery enddiastolic velocities, the expression of ARNT is decreased in comparison to gestational age-matched, appropriately grown controls (Su et al. 2015). Deficient ARNT expression leads to decreased binding of the ARNT/HIF1A transcription factor to hypoxia response elements within the VEGFA proximal promoter, diminished VEGFA expression and impaired proxies of angiogenesis such as tube formation (Su et al. 2015).

\section{Conclusion}

Placental blood flow, both within the fetoplacental and the maternal uteroplacental vasculatures, is critical for pregnancy outcome. Knowledge surrounding the mechanisms underlying both normal and impaired human placental blood flows is limited for several reasons. First, much of the determinants of uteroplacental blood flow are established at or soon after implantation, oftentimes prior to the parturient even knowing she is pregnant. Second, clinical modalities such as Doppler velocimetry of the uterine or umbilical circulations may identify pregnancies at high risk for placental insufficiency, but their utility is limited by the fact that mechanistic investigation cannot occur until after delivery of the infant and placenta. Finally, utilizing the diagnosis of FGR or PE to better investigate mechanisms of abnormal placental function has its limitations. For example, there are likely various mechanisms leading to the same clinical phenotype such as PE or FGR, which is likely why prophylactic measures such as heparin or baby aspirin have limited efficacy, even in high-risk pregnancies. (Bujold et al. 2010, Dodd et al. 2013, Odibo et al. 2015). This is supported by the discrepancies in expression or mechanistic findings in FGR and/or PE. Continued future investigation is warranted in mechanisms underlying maternal and fetoplacental blood flows.

\section{Declaration of interest}

$\mathrm{Dr} \mathrm{Su}$ is a co-investigator on a multicenter, industry-sponsored grant (Progenity, Inc., Evaluation of Preeclampsia Biomarkers).

\section{Funding}

This work was supported by the National Institutes of Health HL119846 (E J S).

\section{Acknowledgements}

The authors are grateful to KIMEN Design for Research (kimendesign4research.com) for their assistance with the figures.

\section{References}

Alfirevic Z, Stampalija T \& Gyte GM 2013 Fetal and umbilical Doppler ultrasound in high-risk pregnancies. Cochrane Database of Systematic Reviews 11 CD007529. (https://doi.org/10.1002/14651858.CD007529. pub3)

Alfirevic Z, Stampalija T \& Dowswell T 2017 Fetal and umbilical Doppler ultrasound in high-risk pregnancies. Cochrane Database of Systematic Reviews 6 CD007529. (https://doi.org/10.1002/14651858.CD007529. pub2)

Allen J, Lauridsen V, Hansen V, Andersson KE \& Forman A 1989 Effects of indomethacin on human placental stem villous arteries. Gynecologic and Obstetric Investigation 27 118-121. (https://doi. org/10.1159/000293635)

Anteby EY, Natanson-Yaron S, Hamani Y, Sciaki Y, Goldman-Wohl D, Greenfield C, Ariel I \& Yagel S 2005 Fibroblast growth factor-10 and fibroblast growth factor receptors 1-4: expression and peptide localization in human decidua and placenta. European Journal of Obstetrics and Gynecology and Reproductive Biology 119 27-35. (https:// doi.org/10.1016/j.ejogrb.2004.05.014)

Arany E \& Hill DJ 1998 Fibroblast growth factor-2 and fibroblast growth factor receptor-1 mRNA expression and peptide localization in placentae from normal and diabetic pregnancies. Placenta 19 133-142. (https://doi.org/10.1016/S0143-4004(98)90001-7)

Autiero M, Luttun A, Tjwa M \& Carmeliet P 2003a Placental growth factor and its receptor, vascular endothelial growth factor receptor-1: novel targets for stimulation of ischemic tissue revascularization and inhibition of angiogenic and inflammatory disorders. Journal of Thrombosis and Haemostasis 1 1356-1370. (https://doi. org/10.1046/j.1538-7836.2003.00263.x)

Autiero M, Waltenberger J, Communi D, Kranz A, Moons L, Lambrechts D, Kroll J, Plaisance S, De Mol M, Bono F, et al. 2003b Role of PlGF in the intra- and intermolecular cross talk between the VEGF receptors Flt1 and Flk1. Nature Medicine 9 936-943. (https:// doi.org/10.1038/nm884)

Barker DJ \& Thornburg KL 2013 The obstetric origins of health for a lifetime. Clinical Obstetrics and Gynecology 56 511-519. (https://doi. org/10.1097/GRF.0b013e31829cb9ca)

Barry JS, Rozance PJ \& Anthony RV 2008 An animal model of placental insufficiency-induced intrauterine growth restriction. Seminars in Perinatology 32 225-230. (https://doi.org/10.1053/j. semperi.2007.11.004)

Bartsch E, Medcalf KE, Park AL, Ray JG \& High Risk of Pre-eclampsia Identification G 2016 Clinical risk factors for pre-eclampsia determined in early pregnancy: systematic review and meta-analysis of large cohort studies. BMJ 353 i1753. (https://doi.org/10.1136/bmj. i1753)

Baschat AA \& Weiner CP 2000 Umbilical artery doppler screening for detection of the small fetus in need of antepartum surveillance. American Journal of Obstetrics and Gynecology 182 154-158. (https:// doi.org/10.1016/S0002-9378(00)70505-9)

Beenken A \& Mohammadi M 2009 The FGF family: biology, pathophysiology and therapy. Nature Reviews Drug Discovery 8 235-253. (https://doi.org/10.1038/nrd2792)

Benirschke K, Burton GJ \& Baergen RN 2012 Pathology of the Human Placenta. Berlin, Germany: Springer-Verlag.

Bird IM, Zhang L \& Magness RR 2003 Possible mechanisms underlying pregnancy-induced changes in uterine artery endothelial function. American Journal of Physiology: Regulatory, Integrative and Comparative Physiology 284 R245-R258. (https://doi.org/10.1152/ ajpregu.00108.2002)

Borras D, Perales-Puchalt A, Ruiz Sacedon N \& Perales A 2014 Angiogenic growth factors in maternal and fetal serum in pregnancies complicated with intrauterine growth restriction. Journal of Obstetrics and Gynaecology 34 218-220. (https://doi.org/10.3109/01 443615.2013.834304) 
Boura AL \& Walters WA 1991 Autacoids and the control of vascular tone in the human umbilical-placental circulation. Placenta 12 453-477. (https://doi.org/10.1016/0143-4004(91)90023-9)

Broegger T, Andersson KE, Aalkjaer C, Forman A \& Boedtkjer DB 2016 Sensitivity to the thromboxane A2 analog U46619 varies with inner diameter in human stem villous arteries. Placenta 39 111-115. (https://doi.org/10.1016/j.placenta.2016.01.017)

Brosens I, Robertson WB \& Dixon HG 1967 The physiological response of the vessels of the placental bed to normal pregnancy. Journal of Pathology and Bacteriology 93 569-579. (https://doi.org/10.1002/ path.1700930218)

Brosens IA, Robertson WB \& Dixon HG 1972 The role of the spiral arteries in the pathogenesis of preeclampsia. Obstetrics and Gynecology Annual 1 177-191.

Brosens I, Dixon HG \& Robertson WB 1977 Fetal growth retardation and the arteries of the placental bed. British Journal of Obstetrics and Gynaecology 84 656-663. (https://doi.org/10.1111/j.1471-0528.1977. tb12676.x)

Bujold E, Roberge S, Lacasse Y, Bureau M, Audibert F, Marcoux S, Forest JC \& Giguere Y 2010 Prevention of preeclampsia and intrauterine growth restriction with aspirin started in early pregnancy: a meta-analysis. Obstetrics and Gynecology 116 402-414 (https://doi.org/10.1097/AOG.0b013e3181e9322a)

Burton GJ \& Jauniaux E 1995 Sonographic, stereological and Doppler flow velocimetric assessments of placental maturity. British Journal of Obstetrics and Gynaecology 102 818-825. (https://doi. org/10.1111/j.1471-0528.1995.tb10849.x)

Carmeliet P, Ferreira V, Breier G, Pollefeyt S, Kieckens L, Gertsenstein M Fahrig M, Vandenhoeck A, Harpal K, Eberhardt C, et al. 1996 Abnormal blood vessel development and lethality in embryos lacking a single VEGF allele. Nature 380 435-439. (https://doi. org/10.1038/380435a0)

Carr DJ, David AL, Aitken RP, Milne JS, Borowicz PP, Wallace JM \& Redmer DA 2016 Placental vascularity and markers of angiogenesis in relation to prenatal growth status in overnourished adolescent ewes. Placenta 46 79-86. (https://doi.org/10.1016/j. placenta.2016.08.076)

Castellucci M \& Kaufmann P 1982 A three-dimensional study of the normal human placental villous core: II. Stromal architecture. Placenta 3 269-285. (https://doi.org/10.1016/S0143-4004(82)80004-0)

Castellucci M, Scheper M, Scheffen I, Celona A \& Kaufmann P 1990 The development of the human placental villous tree. Anatomy and Embryology 181 117-128.

Chen WS, Xu PZ, Gottlob K, Chen ML, Sokol K, Shiyanova T, Roninson I, Weng W, Suzuki R, Tobe K, et al. 2001 Growth retardation and increased apoptosis in mice with homozygous disruption of the Akt1 gene. Genes and Development 15 2203-2208. (https://doi.org/10.1101/gad.913901)

Chen CP, Bajoria R \& Aplin JD 2002 Decreased vascularization and cell proliferation in placentas of intrauterine growth-restricted fetuses with abnormal umbilical artery flow velocity waveforms. American Journal of Obstetrics and Gynecology 187 764-769. (https://doi. org/10.1067/mob.2002.125243)

Damsky CH, Fitzgerald ML \& Fisher SJ 1992 Distribution patterns of extracellular matrix components and adhesion receptors are intricately modulated during first trimester cytotrophoblast differentiation along the invasive pathway, in vivo. Journal of Clinical Investigation 89 210-222. (https://doi.org/10.1172/JCI115565)

Damsky CH, Librach C, Lim KH, Fitzgerald ML, McMaster MT, Janatpour M, Zhou Y, Logan SK \& Fisher SJ 1994 Integrin switching regulates normal trophoblast invasion. Development 120 3657-3666.

De A, Maulik D, Lankachandra K, Mundy DC, Ye SQ \& Gerkovich MM 2016 Fetoplacental regional variations in the expression of angiopoietin-1, angiopoietin-2, and Tie2 in normal-term and nearterm pregnancies. Journal of Maternal-Fetal and Neonatal Medicine 29 3421-3428. (https://doi.org/10.3109/14767058.2015.1136282)
Dekker GA 1999 Risk factors for preeclampsia. Clinical Obstetrics and Gynecology 42 422-435. (https://doi.org/10.1097/00003081199909000-00002)

Demir R, Kaufmann P, Castellucci M, Erbengi T \& Kotowski A 1989 Fetal vasculogenesis and angiogenesis in human placental villi. Acta Anatomica 136 190-203. (https://doi.org/10.1159/000146886)

Demir R, Kayisli UA, Seval Y, Celik-Ozenci C, Korgun ET, DemirWeusten AY \& Huppertz B 2004 Sequential expression of VEGF and its receptors in human placental villi during very early pregnancy: differences between placental vasculogenesis and angiogenesis. Placenta 25 560-572. (https://doi.org/10.1016/j.placenta.2003.11.011)

Dodd JM, McLeod A, Windrim RC \& Kingdom J 2013 Antithrombotic therapy for improving maternal or infant health outcomes in women considered at risk of placental dysfunction. Cochrane Database of Systematic Reviews 7 CD006780. (https://doi. org/10.1002/14651858.CD006780.pub3)

Dunk C, Shams M, Nijjar S, Rhaman M, Qiu Y, Bussolati B \& Ahmed A 2000 Angiopoietin-1 and angiopoietin-2 activate trophoblast Tie-2 to promote growth and migration during placental development. American Journal of Pathology 156 2185-2199. (https://doi. org/10.1016/S0002-9440(10)65089-4)

Enders AC 1989 Trophoblast differentiation during the transition from trophoblastic plate to lacunar stage of implantation in the rhesus monkey and human. American Journal of Anatomy 186 85-98. (https://doi.org/10.1002/aja.1001860107)

Eriksson A, Cao R, Pawliuk R, Berg SM, Tsang M, Zhou D, Fleet C, Tritsaris K, Dissing S, Leboulch P, et al. 2002 Placenta growth factor-1 antagonizes VEGF-induced angiogenesis and tumor growth by the formation of functionally inactive PlGF-1/VEGF heterodimers. Cancer Cell 1 99-108. (https://doi.org/10.1016/S1535-6108(02)00028-4)

Feng L, Liao WX, Luo Q, Zhang HH, Wang W, Zheng J \& Chen DB 2012 Caveolin-1 orchestrates fibroblast growth factor 2 signaling control of angiogenesis in placental artery endothelial cell caveolae. Journal of Cellular Physiology 227 2480-2491. (https://doi.org/10.1002/ jcp.22984)

Ferriani RA, Ahmed A, Sharkey A \& Smith SK 1994 Colocalization of acidic and basic fibroblast growth factor (FGF) in human placenta and the cellular effects of bFGF in trophoblast cell line JEG-3. Growth Factors 10 259-268. (https://doi.org/10.3109/08977199409010992)

Fischer C, Jonckx B, Mazzone M, Zacchigna S, Loges S, Pattarini L, Chorianopoulos E, Liesenborghs L, Koch M, De Mol M, et al. 2007 Anti-PlGF inhibits growth of VEGF(R)-inhibitor-resistant tumors without affecting healthy vessels. Cell 131 463-475. (https://doi. org/10.1016/j.cell.2007.08.038)

Fisher SJ 2015 Why is placentation abnormal in preeclampsia? American Journal of Obstetrics and Gynecology 213 S115-S122. (https://doi. org/10.1016/j.ajog.2015.08.042)

Fong GH, Rossant J, Gertsenstein M \& Breitman ML 1995 Role of the Flt-1 receptor tyrosine kinase in regulating the assembly of vascular endothelium. Nature 376 66-70. (https://doi.org/10.1038/376066a0)

Fox SB \& Khong TY 1990 Lack of innervation of human umbilical cord. An immunohistological and histochemical study. Placenta 11 59-62. (https://doi.org/10.1016/S0143-4004(05)80443-6)

Garcia B, Llurba E, Valle L, Gomez-Roig MD, Juan M, Perez-Matos C, Fernandez M, Garcia-Hernandez JA, Alijotas-Reig J, Higueras MT, et al. 2016 Do knowledge of uterine artery resistance in the second trimester and targeted surveillance improve maternal and perinatal outcome? UTOPIA study: a randomized controlled trial. Ultrasound in Obstetrics and Gynecology 47 680-689. (https://doi.org/10.1002/ uog.15873)

Geva E, Ginzinger DG, Zaloudek CJ, Moore DH, Byrne A \& Jaffe RB 2002 Human placental vascular development: vasculogenic and angiogenic (branching and nonbranching) transformation is regulated by vascular endothelial growth factor-A, angiopoietin-1, and angiopoietin-2. Journal of Clinical Endocrinology and Metabolism 87 4213-4224. (https://doi.org/10.1210/jc.2002-020195) 
Giles WB, Trudinger BJ \& Baird PJ 1985 Fetal umbilical artery flow velocity waveforms and placental resistance: pathological correlation. British Journal of Obstetrics and Gynaecology 92 31-38. (https://doi.org/10.1111/j.1471-0528.1985.tb01045.x)

Glance DG, Elder MG \& Myatt L 1986 The actions of prostaglandins and their interactions with angiotensin II in the isolated perfused human placental cotyledon. British Journal of Obstetrics and Gynaecology 93 488494. (https://doi.org/10.1111/j.1471-0528.1986.tb07935.x)

Goldman-Wohl DS, Ariel I, Greenfield C, Lavy Y \& Yagel S 2000 Tie-2 and angiopoietin-2 expression at the fetal-maternal interface: a receptor ligand model for vascular remodelling. Molecular Human Reproduction 6 81-87. (https://doi.org/10.1093/molehr/6.1.81)

Group GS 2003 A randomised trial of timed delivery for the compromised preterm fetus: short term outcomes and Bayesian interpretation. BJOG 110 27-32. (https://doi. org/10.1046/j.1471-0528.2003.02014.x)

Guiot C, Pianta PG \& Todros T 1992 Modelling the feto-placental circulation: 1. A distributed network predicting umbilical haemodynamics throughout pregnancy. Ultrasound in Medicine and Biology 18 535-544. (https://doi.org/10.1016/0301-5629(92)90068-L)

Gurel D, Ozer E, Altunyurt S, Guclu S \& Demir N 2003 Expression of IGR-IR and VEGF and trophoblastic proliferative activity in placentas from pregnancies complicated by IUGR. Pathology: Research and Practice 199 803-809. (https://doi.org/10.1078/03440338-00499)

Hanna J, Goldman-Wohl D, Hamani Y, Avraham I, Greenfield C, Natanson-Yaron S, Prus D, Cohen-Daniel L, Arnon TI, Manaster I, et al. 2006 Decidual NK cells regulate key developmental processes at the human fetal-maternal interface. Nature Medicine 12 10651074. (https://doi.org/10.1038/nm1452)

Harris LK 2010 Review: trophoblast-vascular cell interactions in early pregnancy: how to remodel a vessel. Placenta 31 (Supplement) S93-S98. (https://doi.org/10.1016/j.placenta.2009.12.012)

Harris LK, Keogh RJ, Wareing M, Baker PN, Cartwright JE, Aplin JD \& Whitley GS 2006 Invasive trophoblasts stimulate vascular smooth muscle cell apoptosis by a fas ligand-dependent mechanism. American Journal of Pathology 169 1863-1874. (https://doi. org/10.2353/ajpath.2006.060265)

Helske S, Vuorela P, Carpen O, Hornig C, Weich H \& Halmesmaki E 2001 Expression of vascular endothelial growth factor receptors 1, 2 and 3 in placentas from normal and complicated pregnancies. Molecular Human Reproduction 7 205-210. (https://doi.org/10.1093/ molehr/7.2.205)

Hiby SE, Apps R, Sharkey AM, Farrell LE, Gardner L, Mulder A, Claas FH, Walker JJ, Redman CW, Morgan L, et al. 2010 Maternal activating KIRs protect against human reproductive failure mediated by fetal HLA-C2. Journal of Clinical Investigation 120 4102-4110. (https://doi.org/10.1172/JCI43998)

Hietala R, Pohja-Nylander P, Rutanen EM \& Laatikainen T 2000 Serum insulin-like growth factor binding protein-1 at 16 weeks and subsequent preeclampsia. Obstetrics and Gynecology $95185-$ 189. (https://doi.org/10.1016/S0029-7844(99)00489-5)

Hill DJ, Tevaarwerk GJ, Arany E, Kilkenny D, Gregory M, Langford KS \& Miell J 1995 Fibroblast growth factor-2 (FGF-2) is present in maternal and cord serum, and in the mother is associated with a binding protein immunologically related to the FGF receptor-1. Journal of Clinical Endocrinology and Metabolism 80 1822-1831. (https://doi.org/10.1210/jcem.80.6.7539816)

Howard BC, Kovac CM, Calhoun BC, Hoeldtke NJ \& Napolitano PG 2003 The effects of a cyclo-oxygenase II inhibitor on placental artery production of thromboxane and prostacyclin. American Journal of Obstetrics and Gynecology 189 835-838. (https://doi. org/10.1067/S0002-9378(03)00844-5)

Hustin J \& Schaaps JP 1987 Echographic (corrected) and anatomic studies of the maternotrophoblastic border during the first trimester of pregnancy. American Journal of Obstetrics and
Gynecology 157 162-168. (https://doi.org/10.1016/S00029378(87)80371-X)

Ianosi-Irimie M, Vu HV, Whitbred JM, Pridjian CA, Nadig JD, Williams MY, Wrenn DC, Pridjian G \& Puschett JB 2005 A rat model of preeclampsia. Clinical and Experimental Hypertension 27 605-617. (https://doi.org/10.1080/10641960500298608)

Jackson MR, Walsh AJ, Morrow RJ, Mullen JB, Lye SJ \& Ritchie JW 1995 Reduced placental villous tree elaboration in small-for-gestationalage pregnancies: relationship with umbilical artery Doppler waveforms. American Journal of Obstetrics and Gynecology 172 518-525. (https://doi.org/10.1016/0002-9378(95)90566-9)

Jaffe R, Jauniaux E \& Hustin J 1997 Maternal circulation in the firsttrimester human placenta - myth or reality? American Journal of Obstetrics and Gynecology 176 695-705. (https://doi.org/10.1016/ S0002-9378(97)70572-6)

Joo JG, Rigo J Jr, Borzsonyi B, Demendi C \& Kornya L 2017 Placental gene expression of the placental growth factor (PlGF) in intrauterine growth restriction. Journal of Maternal-Fetal and Neonatal Medicine $\mathbf{3 0}$ 1471-1475. (https://doi.org/10.1080/14767058.2016.1219993)

Kam EP, Gardner L, Loke YW \& King A 1999 The role of trophoblast in the physiological change in decidual spiral arteries. Human Reproduction 14 2131-2138. (https://doi.org/10.1093/ humrep/14.8.2131)

Kappou D, Sifakis S, Androutsopoulos V, Konstantinidou A, Spandidos DA \& Papantoniou N 2014 Placental mRNA expression of angiopoietins (Ang)-1, Ang-2 and their receptor Tie-2 is altered in pregnancies complicated by preeclampsia. Placenta 35 718-723. (https://doi.org/10.1016/j.placenta.2014.07.001)

Karumanchi SA \& Stillman IE 2006 In vivo rat model of preeclampsia. Methods in Molecular Medicine 122 393-399.

Kaufmann P, Bruns U, Leiser R, Luckhardt M \& Winterhager E 1985 The fetal vascularisation of term human placental villi. II. Intermediate and terminal villi. Anatomy and Embryology 173 203-214. (https:// doi.org/10.1007/BF00316301)

Kaufmann P, Black S \& Huppertz B 2003 Endovascular trophoblast invasion: implications for the pathogenesis of intrauterine growth retardation and preeclampsia. Biology of Reproduction 69 1-7. (https:// doi.org/10.1095/biolreprod.102.014977)

Khalil RA \& Granger JP 2002 Vascular mechanisms of increased arterial pressure in preeclampsia: lessons from animal models. American Journal of Physiology: Regulatory, Integrative and Comparative Physiology 283 R29-R45. (https://doi.org/10.1152/ajpregu.00762.2001)

Kingdom JC, Burrell SJ \& Kaufmann P 1997 Pathology and clinical implications of abnormal umbilical artery Doppler waveforms Ultrasound in Obstetrics and Gynecology 9 271-286. (https://doi. org/10.1046/j.1469-0705.1997.09040271.x)

Kozak KR, Abbott B \& Hankinson O 1997 ARNT-deficient mice and placental differentiation. Developmental Biology 191 297-305. (https://doi.org/10.1006/dbio.1997.8758)

Krebs C, Macara LM, Leiser R, Bowman AW, Greer IA \& Kingdom JC 1996 Intrauterine growth restriction with absent end-diastolic flow velocity in the umbilical artery is associated with maldevelopment of the placental terminal villous tree. American Journal of Obstetrics and Gynecology 175 1534-1542. (https://doi.org/10.1016/S00029378(96)70103-5)

Lee MY, Luciano AK, Ackah E, Rodriguez-Vita J, Bancroft TA Eichmann A, Simons M, Kyriakides TR, Morales-Ruiz M \& Sessa WC 2014 Endothelial Akt1 mediates angiogenesis by phosphorylating multiple angiogenic substrates. PNAS 111 12865-12870. (https://doi. org/10.1073/pnas.1408472111)

Lees CC, Marlow N, van Wassenaer-Leemhuis A, Arabin B, Bilardo CM, Brezinka C, Calvert S, Derks JB, Diemert A, Duvekot JJ, et al. 20152 year neurodevelopmental and intermediate perinatal outcomes in infants with very preterm fetal growth restriction (TRUFFLE): a randomised trial. Lancet 385 2162-2172. (https://doi.org/10.1016/ S0140-6736(14)62049-3) 
Liao WX, Feng L, Zheng J \& Chen DB 2010 Deciphering mechanisms controlling placental artery endothelial cell migration stimulated by vascular endothelial growth factor. Endocrinology $1513432-3444$ (https://doi.org/10.1210/en.2009-1305)

Librach CL, Werb Z, Fitzgerald ML, Chiu K, Corwin NM, Esteves RA, Grobelny D, Galardy R, Damsky CH \& Fisher SJ 1991 92-kD type IV collagenase mediates invasion of human cytotrophoblasts. Journal of Cell Biology 113 437-449. (https://doi.org/10.1083/jcb.113.2.437)

Luria O, Bar J, Barnea O, Golan A \& Kovo M 2012 Reactivity of blood vessels in response to prostaglandin E2 in placentas from pregnancies complicated by fetal growth restriction. Prenatal Diagnosis 32 417-422. (https://doi.org/10.1002/pd.3827)

Macara L, Kingdom JC, Kohnen G, Bowman AW, Greer IA \& Kaufmann P 1995 Elaboration of stem villous vessels in growth restricted pregnancies with abnormal umbilical artery Doppler waveforms. British Journal of Obstetrics and Gynaecology 102 807-812. (https://doi.org/10.1111/j.1471-0528.1995.tb10847.x)

Macara L, Kingdom JC, Kaufmann P, Kohnen G, Hair J, More IA, Lyall F \& Greer IA 1996 Structural analysis of placental terminal villi from growth-restricted pregnancies with abnormal umbilical artery Doppler waveforms. Placenta 17 37-48. (https://doi.org/10.1016/ S0143-4004(05)80642-3)

Maglione D, Guerriero V, Viglietto G, Delli-Bovi P \& Persico MG 1991 Isolation of a human placenta cDNA coding for a protein related to the vascular permeability factor. PNAS 88 9267-9271. (https://doi. org/10.1073/pnas.88.20.9267)

Mak KK, Gude NM, Walters WA \& Boura AL 1984 Effects of vasoactive autacoids on the human umbilical-fetal placental vasculature. British Journal of Obstetrics and Gynaecology 91 99-106. (https://doi. org/10.1111/j.1471-0528.1984.tb05890.x)

Maltepe E, Schmidt JV, Baunoch D, Bradfield CA \& Simon MC 1997 Abnormal angiogenesis and responses to glucose and oxygen deprivation in mice lacking the protein ARNT. Nature 386 403-407. (https://doi.org/10.1038/386403a0)

Mayhew TM 2002 Fetoplacental angiogenesis during gestation is biphasic, longitudinal and occurs by proliferation and remodelling of vascular endothelial cells. Placenta 23 742-750. (https://doi. org/10.1053/plac.2002.0865)

Mayhew TM, Charnock-Jones DS \& Kaufmann P 2004 Aspects of human fetoplacental vasculogenesis and angiogenesis. III. Changes in complicated pregnancies. Placenta 25 127-139. (https://doi. org/10.1016/j.placenta.2003.10.010)

McCarthy AL, Woolfson RG, Evans BJ, Davies DR, Raju SK \& Poston L 1994 Functional characteristics of small placental arteries. American Journal of Obstetrics and Gynecology 170 945-951. (https://doi. org/10.1016/S0002-9378(94)70311-6)

Myatt L, Eis AL, Brockman DE, Greer IA \& Lyall F 1997 Endothelial nitric oxide synthase in placental villous tissue from normal, preeclamptic and intrauterine growth restricted pregnancies. Human Reproduction 12 167-172. (https://doi.org/10.1093/humrep/12.1.167)

Natanson-Yaron S, Anteby EY, Greenfield C, Goldman-Wohl D, Hamani Y, Hochner-Celnikier D \& Yagel S 2007 FGF 10 and Sprouty 2 modulate trophoblast invasion and branching morphogenesis. Molecular Human Reproduction 13 511-519. (https://doi.org/10.1093/ molehr/gam034)

Nugent JL, Wareing M, Palin V, Sibley CP, Baker PN, Ray DW, Farrow SN \& Jones RL 2013 Chronic glucocorticoid exposure potentiates placental chorionic plate artery constriction: implications for aberrant fetoplacental vascular resistance in fetal growth restriction. Endocrinology 154 876-887. (https://doi.org/10.1210/en.2012-1927)

Odibo AO, Goetzinger KR, Odibo L \& Tuuli MG 2015 Early prediction and aspirin for prevention of pre-eclampsia (EPAPP) study: a randomized controlled trial. Ultrasound in Obstetrics and Gynecology 46 414-418. (https://doi.org/10.1002/uog.14889)

Palmer SK, Moore LG, Young D, Cregger B, Berman JC \& Zamudio S 1999 Altered blood pressure course during normal pregnancy and increased preeclampsia at high altitude (3100 meters) in Colorado. American Journal of Obstetrics and Gynecology 180 11611168. (https://doi.org/10.1016/S0002-9378(99)70611-3)

Parham P \& Moffett A 2013 Variable NK cell receptors and their MHC class I ligands in immunity, reproduction and human evolution. Nature Reviews Immunology 13 133-144. (https://doi.org/10.1038/ nri3370)

Park JE, Chen HH, Winer J, Houck KA \& Ferrara N 1994 Placenta growth factor. Potentiation of vascular endothelial growth factor bioactivity, in vitro and in vivo, and high affinity binding to Flt-1 but not to Flk-1/KDR. Journal of Biological Chemistry $26925646-25654$.

Pijnenborg R, Dixon G, Robertson WB \& Brosens I 1980 Trophoblastic invasion of human decidua from 8 to 18 weeks of pregnancy. Placenta 1 3-19. (https://doi.org/10.1016/S01434004(80)80012-9)

Pijnenborg R, Bland JM, Robertson WB \& Brosens I 1983 Uteroplacental arterial changes related to interstitial trophoblast migration in early human pregnancy. Placenta 4 397-413. (https://doi.org/10.1016/S01434004(83)80043-5)

Pijnenborg R, Vercruysse L \& Hanssens M 2006 The uterine spiral arteries in human pregnancy: facts and controversies. Placenta $\mathbf{2 7}$ 939-958. (https://doi.org/10.1016/j.placenta.2005.12.006)

Polydorides AD, Kalish RB, Witkin SS \& Baergen RN 2007 A fetal cyclooxygenase- 2 gene polymorphism is associated with placental malperfusion. International Journal of Gynecological Pathology 26 284-290. (https://doi.org/10.1097/01.pgp.0000236950.56785.a8)

Poston L, McCarthy AL \& Ritter JM 1995 Control of vascular resistance in the maternal and feto-placental arterial beds. Pharmacology amd Therapeutics 65 215-239. (https://doi.org/10.1016/01637258(94)00064-A)

Rankin JH, Goodman A \& Phernetton T 1975 Local regulation of the uterine blood flow by the umbilical circulation. Proceedings of the Society for Experimental Biology and Medicine 150 690-694. (https:// doi.org/10.3181/00379727-150-39107)

Red-Horse K, Kapidzic M, Zhou Y, Feng KT, Singh H \& Fisher SJ 2005 EPHB4 regulates chemokine-evoked trophoblast responses: a mechanism for incorporating the human placenta into the maternal circulation. Development 132 4097-4106. (https://doi.org/10.1242/ dev.01971)

Regnault TR, Orbus RJ, de Vrijer B, Davidsen ML, Galan HL, Wilkening RB \& Anthony RV 2002 Placental expression of VEGF, PlGF and their receptors in a model of placental insufficiencyintrauterine growth restriction (PI-IUGR). Placenta 23 132-144. (https://doi.org/10.1053/plac.2001.0757)

Reilly FD \& Russell PT 1977 Neurohistochemical evidence supporting an absence of adrenergic and cholinergic innervation in the human placenta and umbilical cord. Anatomical Record 188 277-286. (https://doi.org/10.1002/ar.1091880302

Reister F, Frank HG, Heyl W, Kosanke G, Huppertz B, Schroder W, Kaufmann P \& Rath W 1999 The distribution of macrophages in spiral arteries of the placental bed in pre-eclampsia differs from that in healthy patients. Placenta 20 229-233. (https://doi.org/10.1053/ plac.1998.0373)

Reister F, Frank HG, Kingdom JC, Heyl W, Kaufmann P, Rath W \& Huppertz B 2001 Macrophage-induced apoptosis limits endovascular trophoblast invasion in the uterine wall of preeclamptic women. Laboratory Investigation 81 1143-1152. (https://doi.org/10.1038/ labinvest.3780326)

Rizzo G, Capponi A, Rinaldo D, Arduini D \& Romanini C 1996 Release of vasoactive agents during cordocentesis: differences between normally grown and growth-restricted fetuses. American Journal of Obstetrics and Gynecology 175 563-570. (https://doi.org/10.1053/ ob.1996.v175.a74253)

Rodesch F, Simon P, Donner C \& Jauniaux E 1992 Oxygen measurements in endometrial and trophoblastic tissues during early pregnancy. Obstetrics and Gynecology 80 283-285. 
Sabry S, Mondon F, Ferre F \& Dinh-Xuan AT 1995 In vitro contractile and relaxant responses of human resistance placental stem villi arteries of healthy parturients: role of endothelium. Fundamental and Clinical Pharmacology 9 46-51. (https://doi. org/10.1111/j.1472-8206.1995.tb00264.x)

Sadler TW 1995 Langman's Meical Embryology. Baltimore, MD, USA: Williams and Wilkins.

Salafia CM, Minior VK, Pezzullo JC, Popek EJ, Rosenkrantz TS \& Vintzileos AM 1995 Intrauterine growth restriction in infants of less than thirty-two weeks' gestation: associated placental pathologic features. American Journal of Obstetrics and Gynecology 173 1049-1057. (https://doi.org/10.1016/0002-9378(95)91325-4)

Salafia CM, Pezzullo JC, Minior VK \& Divon MY 1997 Placental pathology of absent and reversed end-diastolic flow in growthrestricted fetuses. Obstetrics and Gynecology 90 830-836. (https://doi. org/10.1016/S0029-7844(97)00473-0)

Sastry BV, Hemontolor ME, Chance MB \& Johnson RF 1997 Dual messenger function for prostaglandin E2 (PGE2) in human placenta. Cellular and Molecular Biology 43 417-424.

Savvidou MD, Hingorani AD, Tsikas D, Frolich JC, Vallance P \& Nicolaides KH 2003 Endothelial dysfunction and raised plasma concentrations of asymmetric dimethylarginine in pregnant women who subsequently develop pre-eclampsia. Lancet 361 1511-1517. (https://doi.org/10.1016/S0140-6736(03)13177-7)

Schlafke S \& Enders AC 1975 Cellular basis of interaction between trophoblast and uterus at implantation. Biology of Reproduction 12 41-65. (https://doi.org/10.1095/biolreprod12.1.41)

Seval Y, Sati L, Celik-Ozenci C, Taskin O \& Demir R 2008 The distribution of angiopoietin-1, angiopoietin-2 and their receptors tie- 1 and tie- 2 in the very early human placenta. Placenta 29 809-815. (https://doi.org/10.1016/j.placenta.2008.06.009)

Shalaby F, Rossant J, Yamaguchi TP, Gertsenstein M, Wu XF, Breitman ML \& Schuh AC 1995 Failure of blood-island formation and vasculogenesis in Flk-1-deficient mice. Nature 376 62-66. (https://doi.org/10.1038/376062a0)

Shams M \& Ahmed A 1994 Localization of mRNA for basic fibroblast growth factor in human placenta. Growth Factors 11 105-111. (https://doi.org/10.3109/08977199409001052)

Shimonovitz S, Hurwitz A, Dushnik M, Anteby E, Geva-Eldar T \& Yagel S 1994 Developmental regulation of the expression of 72 and $92 \mathrm{kd}$ type IV collagenases in human trophoblasts: a possible mechanism for control of trophoblast invasion. American Journal of Obstetrics and Gynecology 171 832-838. (https://doi.org/10.1016/00029378(94)90107-4)

Sladek SM, Magness RR \& Conrad KP 1997 Nitric oxide and pregnancy. American Journal of Physiology 272 R441-R463.

Stock MK, Anderson DF, Phernetton TM, McLaughlin MK \& Rankin JH 1980 Vascular response of the fetal placenta to local occlusion of the maternal placental vasculature. Journal of Developmental Physiology 2 339-346.

Su EJ, Lin ZH, Zeine R, Yin P, Reierstad S, Innes JE \& Bulun SE 2009 Estrogen receptor-beta mediates cyclooxygenase-2 expression and vascular prostanoid levels in human placental villous endothelial cells. American Journal of Obstetrics and Gynecology 200427 e421-e428. (https://doi.org/10.1016/j.ajog.2008.07.069)

Su EJ, Ernst L, Abdallah N, Chatterton R, Xin H, Monsivais D, Coon J \& Bulun SE 2011 Estrogen receptor-beta and fetoplacental endothelial prostanoid biosynthesis: a link to clinically demonstrated fetal growth restriction. Journal of Clinical Endocrinology and Metabolism 96 E1558-E1567. (https://doi.org/10.1210/jc.2011-1084)

Su EJ, Xin H, Yin P, Dyson M, Coon J, Farrow KN, Mestan KK \& Ernst LM 2015 Impaired fetoplacental angiogenesis in growthrestricted fetuses with abnormal umbilical artery doppler velocimetry is mediated by aryl hydrocarbon receptor nuclear translocator (ARNT). Journal of Clinical Endocrinology and Metabolism 100 E30E40. (https://doi.org/10.1210/jc.2014-2385)
Szentpeteri I, Rab A, Kornya L, Kovacs P \& Joo JG 2013 Gene expression patterns of vascular endothelial growth factor (VEGF-A) in human placenta from pregnancies with intrauterine growth restriction. Journal of Maternal-Fetal and Neonatal Medicine 26 984-989. (https:// doi.org/10.3109/14767058.2013.766702)

Thompson RS \& Trudinger BJ 1990 Doppler waveform pulsatility index and resistance, pressure and flow in the umbilical placental circulation: an investigation using a mathematical model. Ultrasound in Medicine and Biology 16 449-458. (https://doi.org/10.1016/03015629(90)90167-B)

Thornton JG, Hornbuckle J, Vail A, Spiegelhalter DJ, Levene M \& group Gs 2004 Infant wellbeing at 2 years of age in the Growth Restriction Intervention Trial (GRIT): multicentred randomised controlled trial. Lancet 364 513-520. (https://doi.org/10.1016/ S0140-6736(04)16809-8)

Todros T, Guiot C \& Pianta PG 1992 Modelling the feto-placental circulation: 2. A continuous approach to explain normal and abnormal flow velocity waveforms in the umbilical arteries. Ultrasound in Medicine and Biology 18 545-551. (https://doi. org/10.1016/0301-5629(92)90069-M)

Todros T, Sciarrone A, Piccoli E, Guiot C, Kaufmann P \& Kingdom J 1999 Umbilical Doppler waveforms and placental villous angiogenesis in pregnancies complicated by fetal growth restriction. Obstetrics and Gynecology 93 499-503. (https://doi.org/10.1016/ S0029-7844(98)00440-2)

Tran QK, Leonard J, Black DJ, Nadeau OW, Boulatnikov IG \& Persechini A 2009 Effects of combined phosphorylation at Ser-617 and Ser-1179 in endothelial nitric-oxide synthase on EC50(Ca2+) values for calmodulin binding and enzyme activation. Journal of Biological Chemistry 284 11892-11899. (https://doi.org/10.1074/jbc. M806205200)

Trudinger BJ, Giles WB \& Cook CM 1985a Flow velocity waveforms in the maternal uteroplacental and fetal umbilical placental circulations. American Journal of Obstetrics and Gynecology 152 155-163. (https://doi.org/10.1016/S0002-9378(85)80016-8)

Trudinger BJ, Giles WB \& Cook CM 1985b Uteroplacental blood flow velocity-time waveforms in normal and complicated pregnancy. British Journal of Obstetrics and Gynaecology 92 39-45. (https://doi. org/10.1111/j.1471-0528.1985.tb01046.x)

Trudinger BJ, Giles WB, Cook CM, Bombardieri J \& Collins L 1985c Fetal umbilical artery flow velocity waveforms and placental resistance: clinical significance. British Journal of Obstetrics and Gynaecology 92 23-30. (https://doi.org/10.1111/j.1471-0528.1985.tb01044.x)

van Oppenraaij RH, Koning AH, Lisman BA, Boer K, van den Hoff MJ, van der Spek PJ, Steegers EA \& Exalto N 2009 Vasculogenesis and angiogenesis in the first trimester human placenta: an innovative 3D study using an immersive Virtual Reality system. Placenta 30 220-222. (https://doi.org/10.1016/j.placenta.2008.12.014)

Vatten LJ, Nilsen TI, Juul A, Jeansson S, Jenum PA \& Eskild A 2008 Changes in circulating level of IGF-I and IGF-binding protein-1 from the first to second trimester as predictors of preeclampsia. European Journal of Endocrinology 158 101-105. (https://doi.org/10.1530/EJE07-0386)

$\mathrm{Xu}$ L, Cochran DM, Tong RT, Winkler F, Kashiwagi S, Jain RK \& Fukumura D 2006 Placenta growth factor overexpression inhibits tumor growth, angiogenesis, and metastasis by depleting vascular endothelial growth factor homodimers in orthotopic mouse models. Cancer Research 66 3971-3977. (https://doi.org/10.1158/0008-5472. CAN-04-3085)

Yang ZZ, Tschopp O, Hemmings-Mieszczak M, Feng J, Brodbeck D, Perentes E \& Hemmings BA 2003 Protein kinase B alpha/Akt1 regulates placental development and fetal growth. Journal of Biological Chemistry 278 32124-32131. (https://doi.org/10.1074/jbc. M302847200)

Yang X, Zhang Y, Yang Y, Lim S, Cao Z, Rak J \& Cao Y 2013 Vascular endothelial growth factor-dependent spatiotemporal dual roles of 
placental growth factor in modulation of angiogenesis and tumor growth. PNAS 110 13932-13937. (https://doi.org/10.1073/ pnas.1309629110)

Yi FX, Boeldt DS, Gifford SM, Sullivan JA, Grummer MA, Magness RR \& Bird IM 2010 Pregnancy enhances sustained Ca2+ bursts and endothelial nitric oxide synthase activation in ovine uterine artery endothelial cells through increased connexin 43 function. Biology of Reproduction 82 66-75. (https://doi.org/10.1095/biolreprod.109.078253)

Yi FX, Boeldt DS, Magness RR \& Bird IM 2011 [Ca2+]i signaling vs. eNOS expression as determinants of NO output in uterine artery endothelium: relative roles in pregnancy adaptation and reversal by VEGF165. American Journal of Physiology: Heart and Circulatory Physiology 300 H1182-H1193. (https://doi.org/10.1152/ ajpheart.01108.2010)

Zamudio S 2007 High-altitude hypoxia and preeclampsia. Frontiers in Bioscience 12 2967-2977. (https://doi.org/10.2741/2286)

Zhang EG, Smith SK, Baker PN \& Charnock-Jones DS 2001 The regulation and localization of angiopoietin-1, -2 , and their receptor Tie2 in normal and pathologic human placentae. Molecular Medicine 7 624-635.
Zheng J, Wen Y, Song Y, Wang K, Chen DB \& Magness RR 2008 Activation of multiple signaling pathways is critical for fibroblast growth factor 2- and vascular endothelial growth factor-stimulated ovine fetoplacental endothelial cell proliferation. Biology of Reproduction 78 143-150. (https://doi.org/10.1095/ biolreprod.107.064477)

Zhou Y, Damsky CH, Chiu K, Roberts JM \& Fisher SJ 1993 Preeclampsia is associated with abnormal expression of adhesion molecules by invasive cytotrophoblasts. Journal of Clinical Investigation 91 950-960. (https://doi.org/10.1172/JCI116316)

Zhou Y, Damsky CH \& Fisher SJ 1997a Preeclampsia is associated with failure of human cytotrophoblasts to mimic a vascular adhesion phenotype. One cause of defective endovascular invasion in this syndrome? Journal of Clinical Investigation 99 2152-2164. (https:// doi.org/10.1172/JCI119388)

Zhou Y, Fisher SJ, Janatpour M, Genbacev O, Dejana E, Wheelock M \& Damsky CH 1997b Human cytotrophoblasts adopt a vascular phenotype as they differentiate. A strategy for successful endovascular invasion? Journal of Clinical Investigation 99 2139-2151. (https://doi.org/10.1172/JCI119387)

Received in final form 19 October 2017

Accepted 2 November 2017

Accepted preprint published online 2 November 2017 http://jme.endocrinology-journals.org https://doi.org/10.1530/JME-17-0139 (c) 2018 Society for Endocrinology Published by Bioscientifica Ltd. Printed in Great Britain 